\title{
FOREST RECREATION MOVES AHEAD IN ONTARIO
}

\author{
BY A. B. WHEATLEY 1
}

A. B. Wheatley attended primary and secondary schools in Sarnia, Ontario. He graduated from the University of Toronto with a B.Sc.F. in 1930. Mr. Wheatley has been employed by the Ontario Department of Lands and Forests in the following positions: 1930-1941, Reforestation work and County Forests; 1941-1946, District Forester, Kemptville, Ont.; 1946-1954, District Forester, Lindsay, Ont.; 1954-1956, District Forester, Aylmer, Ont.; 1956-1960, Asst. Chief, Parks Branch; 1960, Chief, Parks Branch.

\section{SUMMARY}

1. The public right to use and enjoy its forest- and lakeland must be protected.

2. Specially developed areas to provide for wild-land recreational use is necessary to enable people to participate in outdoor experiences. An expanding provincial parks system is fundamental to this.

3. Multiple-use of public lands, including parks, is fundamental to a full land use concept. A waste of a resource is contrary to the public interest.

4. There should always be a practice of reserving public lands for park purposes, incorporating the multiple-use concept, in order to avoid a possible development that is not compatible with the main potentials of the land.

5. The recreational resource in forest areas is very real and must be part of a land use plan in which timber production and recreation, being renewable resources, should be reconciled and each developed to provide the maximum public value.

The sprawling area, of more than 400,000 square miles, which makes up the Province of Ontario, is bordered on the south by the equally sprawling Great Lakes, and on the north by the vast spruce forests and muskegs. From this boreal environment of the north, the Province reaches south to a latitude equal to that of northern California, and to a climate which favours the growth of the southern hardwoods. Ontario's mass is unequally divided into two main regions. One, in the south, is blessed with glacial deposits, influenced by sedimentary rocks. This, arable land, coupled with a favourable growing season, and the Great Lakes transportation routes, has become the agricultural and population density centre of the Province. The other region, much larger than the first, is characterized by Precambrian rocks, scraped by Glacial action, and interrupted occasionally by pockets of level clay soils. Throughout this Shield country, the land is splashed with countless lakes and chains of waterways. The soils are thin, but support the bulk of Ontario's present forests. The forests and waters produce game, fur and fish. The Precambrian Shield also possesses most of Ontario's mineral wealth. We may now add to the resources of the Shield, recreation. It is interesting to note, however, that while forestry, fish, wildlife and minerals depend upon removal of these resources, recreation depends upon the presence of forests and the least possible disturbance of the environment. A compromise, therefore, between forestry and recreation has become necessary.

${ }^{1}$ Chief, Parks Branch, Ontario Dept. of Lands and Forests, Toronto, Ont. 
Ontario is probably in a more fortunate position than most other government agencies charged with wide, public administration. This situation is largely due to its land policy which has developed during several generations, and is related to the methods of licensing or authorizing the removal of timber from public lands. No alienation of lands for timber removal has been permitted and, as a result, timber licensing or concession practices have developed to foster forest management plans designed to perpetuate our forests. Much progress towards this end has been made in recent years. Although most land alienations have been limited to those suitable for agriculture, there have been some exceptions, such as railway lands and a few others. In total, however, these represent a small percentage of the area of the Province, of which approximately $85 \%$ is still in public ownership. It has been said that the basic requirements for recreation are woods and water. In addition to the forest lands, there are an estimated one-quarter million lakes, and it should be noted that the beds of lakes and streams have remained in public ownership.

In addition to keeping much of the Province in public ownership, the Province of Ontario has set aside certain strategic areas as provincial parks. The first of these was established in 1893, when Ontario's population was perhaps only a third of its present size. Such parks were established, from time to time, until six years ago, when a much more vigorous approach to a provincial parks system was started. As would be expected, the forest lands of the Precambrian Shield, already in public ownership, provided new parklands. Of the total of 79 provincial parks in operation this year, 49 , or $62 \%$ are on the Shield. The remaining 30 , or $38 \%$, are located in the southern region, along Lake Ontario, Lake Erie, Lake Huron, where public beaches are in great demand, and inland on sub-marginal agricultural lands, which had certain recreational amenities and were available by acquisition. The regional division of provincial parks already changes, however, when we glance at the areas of the parklands. Of the total provincial park area of 5,434 square miles, we find that $99.5 \%$ is on the Precambrian Shield and only $0.5 \%$ is in the south, where the densely populated centres require recreational lands.

In the north, the area of parkland is influenced tremendously by four large parks. These are Algonquin (2,910 sq. mi.), Quetico (1,750 sq. miles), Lake Superior (520 sq. miles) and Sibley (63 sq. miles) Provincial Parks. A park development program must provide for the many recreational needs of people, and experience has indicated that only a small percentage of the total provincial park visitors avail themselves of the wilderness experience of canoe travel; canoe-trippers are increasing yearly and require space for this recreational pursuit. The large parks are managed to give this recreational aspect high priority. The management, however, recognizes that it is in the public interest to harvest timber in the large parks. From this policy, therefore, an optimum management is being developed to provide for both forestry and recreation. This same principle should apply to other renewable resources, such as game and fur, which can be managed with a view to their proper use, improvement and recreational values. Here scientific research, with a policy of multiple-use uppermost, is fundamental, to determine the best system for the management of these resources. At present, we are 
trying out methods whereby it is our hope that we will add to the total recreational potential of these parklands. Even in the southern region, in smaller parks, multiple-use is being attempted this year, in the form of pheasant shooting of stock birds, on a put-and-take basis. In view of the gradually decreasing areas of suitable public shooting grounds near population centres, it is hoped that provincial parks may fill a gap in this form of recreation, and provide a wide variety of recreational opportunities consistent with the primary function of these lands.

To make available adequate access to the wild land environment and, at the same time, provide the necessary maintenance and supervision of such areas, it has become necessary to provide focal points in provincial parks, particularly large ones. This access, in the form of the campground, has been established, with necessary facilities for large numbers of visitors. The wellknown campgrounds seem the only way in which the park environment may be enjoyed by large numbers of family groups.

In addition to provincial parks, there are many millions of acres of forest and lake lands which are available to the more adventurous vacationer, and to the commercial outfitter who provides for the canoe-traveller, the fisherman and the hunter. It is in this vast area where there might appear to be a conflict between the recreation and the use of vital resources, such as timber, minerals, commercial fisheries, etc. It is here, where foresters and forest management requirements must accept a more complete multiple-use concept and include forest recreation.

From the multiple-use point of view, every acre of land has potentials, in addition to its main use. Highly productive agricultural and forest lands also produce game and fur. Lands having the lowest productivity of commercially valuable products may well have a value for game and fur production in excess of any other use. The potential of any lands for recreational use should not be excluded from a land management plan.

Forest management policies, therefore, should incorporate a concept which foresees and designates areas which have a high recreational potential well ahead of the actual need. The exploitation of valuable forest resources should then be managed with recreational values in mind. Here, again, Ontario may be fortunate in the public ownership of most of its forest and lake country. Already many such areas have been included in our inventory of lands suitable for recreational purposes.

With the increasing use of forest lands for camping, fishing, hunting, and general recreation, a number of problems arise:

1. Access points to public waters and their maintenance.

2. Wilderness campsite maintenance.

3. Hunt campsites and their density control.

4. Protection of forest workers against shooting accidents.

5. Budgetary considerations for maintenance and supervisory problems.

6. Use of forest access roads. 
7. Higher incomes, more leisure time, better and more highways will exert pressure upon present wild-land recreational areas, and create a demand for additional areas. Foresters are in a favoured position to relate this type of resource-use to all others on wild-lands administered by them.

8. The pressures for the use of all resources will increase with population growth. The way of life to which North Americans have become accustomed can be assured through the co-opertaion of all resource-user groups. It is worth striving for.

It has been the policy, in Ontario, for many years, to make lakeshore lands available for private and commercial summer resort lands. In order to protect the public right to reach and use the public waters, a great many lake access points have been reserved from sale for this purpose. The problem of maintenance, however, is a substantial one, with which we are still struggling. It involves a rather large expenditure, which ought not to be placed on the forest manager's financial doorstep.

Within our highly organized industrial system, with a short work-week, increasing income, more and better highways, and a strong desire on the part of the public to see and use the nation's recreational resources, it is necessary for the state to protect its citizens' rights to recreational resources. Foresters will have to face this situation and, generally, they have.

How are the costs incurred on account of the public use of our forest lands to be met? It is known that they may be substantial in consideration of only fire prevention and suppression. It is also known that more than half of our forest fires are caused by the forest-travelling public. Add to this the cost of cleaning up after vacationers as well as their supervision.

Ontario's parks system, which plays host to a large percentage of these people, does make charges for the use of park facilities:

Camper Use-family unit

Day Use-one day only

Seasonal Use-all parks

$$
\begin{aligned}
& -\$ 1.00 \text { per day } \\
& -\$ 0.50 \text { per day } \\
& -\$ 3.00 \text { per season }
\end{aligned}
$$

Our objective, here, is that park users, in a few years, should provide in fees a sufficient amount to meet park operation costs. We are approaching this objective.

The use of forest lands for recreational purposes, of course, poses problems not found in our provincial parks system. It has been suggested that our forest travel permits might be a solution.

The value of forest lands for recreational purposes is known. It offers a tremendous scope for healthful enjoyment. Perhaps nowhere in the western world is there such an abundance of wild-lands as in North America, and particularly in Canada. I think that foresters are in an admirable position to provide the leadership whereby our large urban populations, in particular, may secure relaxation and enjoyment in a society of which we should be thankful to be a part. Recently, I had the privilege of an extensive tour through Europe and part of Russia. By comparison, it is well worth our while to assure that the rights of people to use our recreational resources be made secure. 
Finally, a few statistics may offer an indication as to the expanding use made by the public of our park facilities, which are organized to accommodate large numbers of recreation seekers:

\begin{tabular}{ccc}
\hline & Camper Use & Total Visitor Use \\
\hline 1956 & 86,641 & - \\
1957 & 165,055 & $2,114,661$ \\
1958 & 277,183 & $3,232,460$ \\
1959 & 477,069 & $5,106,352$ \\
1960 & 592,103 & $5,672,528$ \\
1961 & 862,559 & $6,215,370$ \\
\hline
\end{tabular}

